\title{
Examining growth monitoring practices for children in primary care
}

\author{
Sarah Carsley, Catherine S. Birken, Karen Tu, Eleanor \\ Pullenayegum, and Patricia C. Parkin
}

Version Post-print/Accepted Manuscript

Citation Carsley, S., Birken, C. S., Tu, K., Pullenayegum, E., \& Parkin, P. C.

(published version) (2017). Examining growth monitoring practices for children in primary care. Archives of disease in childhood, archdischild-2017.

Publisher's This article has been accepted for publication in Archives of Disease in

Statement Childhood, 2017 following peer review, and the Version of Record can be accessed online at 10.1136/archdischild-2017-314016.

Copyright/License

(c) (1) $\ominus$ This work is licensed under the Creative Commons

BY NC ND Attribution-NonCommercial-NoDerivatives 4.0

International License. To view a copy of this license, visit

http://creativecommons.org/licenses/by-nc-nd/4.0/.

How to cite TSpace items

Always cite the published version, so the author(s) will receive recognition through services that track citation counts, e.g. Scopus. If you need to cite the page number of the author manuscript from TSpace because you cannot access the published version, then cite the TSpace version in addition to the published version using the permanent URI (handle) found on the record page.

This article was made openly accessible by $U$ of $T$ Faculty. Please tell us how this access benefits you. Your story matters. 
Examining growth monitoring practices for children in primary care

Sarah Carsley ${ }^{1,2}$, Catherine S. Birken ${ }^{1-3}$, Karen $\mathrm{Tu}^{1,4,5}$, Eleanor Pullenayegum ${ }^{2}$, and Patricia C. Parkin ${ }^{1-3}$

\author{
Affiliations: \\ ${ }^{1}$ Institute for Health Policy, Management and Evaluation, University of Toronto, Toronto, \\ Canada \\ ${ }^{2}$ Peter Gilgan Centre for Research and Learning, Child Health Evaluative Sciences, the Hospital \\ for Sick Children; Pediatric Outcomes Research Team (PORT), Division of Paediatric Medicine, \\ the Hospital for Sick Children, Toronto, Canada \\ ${ }^{3}$ Department of Pediatric Medicine, University of Toronto, Toronto, Canada \\ ${ }^{4}$ Department of Family and Community Medicine, University of Toronto, Toronto, Canada \\ ${ }^{5}$ Toronto Western Hospital Family Health Team, University Health Network, Toronto, Canada
}

\title{
Address correspondence to:
}

Patricia Parkin

Division of Paediatric Medicine, The Hospital for Sick Children,

$10^{\text {th }}$ Floor - Peter Gilgan Centre for Research and Learning

686 Bay Street, Toronto, ON, M5G 0A4, Canada

Email: patricia.parkin@ sickkids.ca 
Growth monitoring is the long-standing practice used to identify children who fall outside healthy growth parameters. It has been proposed as a key activity for childhood obesity prevention. ${ }^{1}$ Accurate growth monitoring requires specific techniques and equipment, and plotting measurements on a growth chart. The objective of this study was to determine if primary care providers follow recommended growth monitoring practices, including measurement techniques, standardized equipment, and use of appropriate growth charts at all health visits.

An electronic survey was distributed between December 2016 and February 2017. The sampling frame was health professionals (physicians, dietitians, nurses) most responsible for growth measurement in primary care practices in the province of Ontario, Canada. The survey assessed the following: measurement equipment, technique, growth chart use, and timing (scheduled and/or unscheduled visits). Respondent practice discipline was collected. Descriptive statistics were performed. Chi-squared and Fisher's exact test were used to assess differences between practitioner discipline.

Seventy-three surveys were completed from physicians (36\%), nurses (26\%), and dietitians (38\%). To measure weight, a digital scale was used of by $93.2 \%$ for infants $<2$ years and $68.5 \%$ for children $\geq 2$ years (Table 1). To measure supine length in infants $<2$ years, $21 \%$ reported using a length board and $60 \%$ reported using the 'paper and pencil' method with a tape measure (Table 2). For children <2 years able to stand, $31.5 \%$ reported using the 'paper and pencil' method and 32.9\% used a stadiometer. Differences between professional disciplines were not statistically significant; however dietitians had the highest adherence to recommendations (Table 2). Growth was measured 'always' at scheduled well-child visits by $80.8 \%$ (height) and $86.3 \%$ 
(weight); and at unscheduled sick visits was 9.6\% (height) and 34.3\% (weight). Reported growth chart use was $85.0 \%$, predominately the WHO chart $(80.0 \%)$.

In this study, we found that adherence to recommendations for use of appropriate equipment and technique for measuring infant and child weight was adequate to high, but for measuring infant length was low. Growth chart use was high, but measurement at unscheduled visits was low. A survey of Primary Care Trusts in the UK found that more than 50\% of children under five years had both weight and height/length measured, almost always by a health visitor; however, equipment, technique and growth chart use were not examined. ${ }^{2}$ A survey of primary care practices in the US showed that correct equipment was used in $22 \%$ for height and $12 \%$ for length. ${ }^{3}$

Limitations of our study include the small number of survey respondents, use of a survey rather than direct observation and the possibility that the findings may not be generalizable to practices throughout the region. These limitations may have resulted in a bias towards higher rates of adherence to current recommendations because many respondents were linked to academic centres. Finally, while we did not assess training of health professionals, the results of our study may be useful for informing future training.

Growth monitoring consists of serial measurement of weight, height/length and calculation of body mass index, with plotting of these measures on a growth chart. Our study suggests growth monitoring can be improved by increasing the use of length boards for children $<2$ years of age, and measuring and charting growth at both scheduled and unscheduled visits. 


\section{References}

1. Canadian Task Force on Preventive Health Care. Recommendations for growth monitoring, and prevention and management of overweight and obesity in children and youth in primary care. CMAJ : Canadian Medical Association journal = journal de l'Association medicale canadienne. Apr 7 2015;187(6):411-421.

2. Patterson L, Jarvis P, Verma A, Harrison R, Buchan I. Measuring children and monitoring obesity: surveys of English Primary Care Trusts 2004-06. Journal of public health (Oxford, England). Dec 2006;28(4):330-336.

3. Lipman TH, Hench K, Logan JD, DiFazio DA, Hale PM, Singer-Granick C. Assessment of growth by primary health care providers. Journal of pediatric health care : official publication of National Association of Pediatric Nurse Associates \& Practitioners. JulAug 2000;14(4):166-171. 
Table 1: Reported Current practices for measurement of weight and child dress by age

\begin{tabular}{lll|lll}
\hline \multicolumn{3}{c|}{ Infant (<2 years) } & \multicolumn{2}{c}{ Child ( $\geq 2$ years) } \\
\hline Infant Weight Equipment & $\mathrm{N}$ & $\%$ & Child Weight Equipment & $\mathrm{N}$ & $\%$ \\
\hline Baby scale (digital) & 68 & 93.15 & Digital or electronic scale & 50 & 68.49 \\
Beam balance scale & 3 & 4.11 & Beam balance scale & 21 & 28.77 \\
No equipment for babies & 1 & 1.37 & Other & 2 & 2.74 \\
Other & 1 & 1.37 & & & \\
\hline Infant Clothing & $\mathbf{N}$ & $\mathbf{\%}$ & Child Clothing & $\mathrm{N}$ & $\%$ \\
\hline Naked & 33 & 45.83 & Light clothes, no shoes & 60 & 83.33 \\
Diaper only & 26 & 36.11 & Light clothes, with shoes & 1 & 1.39 \\
Light clothes & 2 & 2.78 & Fully clothed, no shoes & 8 & 11.11 \\
Fully clothed, no shoes & 2 & 2.78 & Fully clothed, with shoes & 1 & 1.39 \\
Other* & 9 & 12.5 & Other* & 2 & 2.78 \\
\hline
\end{tabular}

*Free text responses specified naked at very young ages $<12$ months, light clothes otherwise

Table 2: Reported current practices for measurement of length and height by age and professional designation

\begin{tabular}{|c|c|c|c|c|c|c|c|c|c|c|}
\hline \multirow{2}{*}{$\begin{array}{l}\text { Age } \\
\text { group }\end{array}$} & \multirow[t]{2}{*}{ Equipment for length/height } & \multicolumn{2}{|c|}{ Total } & \multicolumn{2}{|c|}{ Physician } & \multicolumn{2}{|c|}{ Nurse } & \multicolumn{2}{|c|}{ Dietitian } & \multirow[t]{2}{*}{ p-value } \\
\hline & & $\mathrm{N}$ & $\%$ & $\mathrm{~N}$ & $\%$ & $\mathrm{~N}$ & $\%$ & $\mathrm{~N}$ & $\%$ & \\
\hline \multirow{3}{*}{$<2$ years } & Length Board & 15 & $21 \%$ & 5 & $19 \%$ & 2 & $12 \%$ & 8 & $29 \%$ & \multirow[t]{3}{*}{0.12} \\
\hline & Paper pencil & 44 & $60 \%$ & 13 & $50 \%$ & 14 & $82 \%$ & 17 & $61 \%$ & \\
\hline & Other & 12 & $16 \%$ & 8 & $31 \%$ & 1 & $6 \%$ & 3 & $11 \%$ & \\
\hline \multirow{6}{*}{$\begin{array}{l}<2 \\
\text { years, } \\
\text { but } \\
\text { child } \\
\text { can } \\
\text { stand }\end{array}$} & Length Board & 5 & $7 \%$ & 1 & $4 \%$ & 1 & $6 \%$ & 3 & $11 \%$ & \multirow[t]{6}{*}{0.07} \\
\hline & Stadiometer & 25 & $34 \%$ & 11 & $42 \%$ & 4 & $24 \%$ & 10 & $36 \%$ & \\
\hline & Paper pencil & 23 & $32 \%$ & 5 & $19 \%$ & 10 & $59 \%$ & 6 & $21 \%$ & \\
\hline & Tape measure on wall/ & 14 & $19 \%$ & 5 & $19 \%$ & 0 & $0 \%$ & 1 & $4 \%$ & \\
\hline & Standing measuring stick & & & & & & & & & \\
\hline & Other & 6 & $8 \%$ & 4 & $15 \%$ & 2 & $12 \%$ & 8 & $29 \%$ & \\
\hline \multirow{4}{*}{$\begin{array}{l}\geq 2 \\
\text { years }\end{array}$} & Stadiometer & 47 & $64 \%$ & 16 & $62 \%$ & 9 & $53 \%$ & 21 & $75 \%$ & \multirow[t]{4}{*}{0.59} \\
\hline & Tape measure on wall/ & 22 & $30 \%$ & 8 & $31 \%$ & 7 & $41 \%$ & 6 & $21 \%$ & \\
\hline & Standing & & & & & & & & & \\
\hline & Other & 4 & $6 \%$ & 2 & $8 \%$ & 1 & $6 \%$ & 1 & $4 \%$ & \\
\hline
\end{tabular}

